\title{
The Education of Art Museum Professionals
}

By

Yi-Chien Chen

Florida State University 


\section{Introduction}

The definition of museum is always changing. Whether a shrine (Sikes, 1992; Pope-Hennessy, 1994), a warehouse (Margolis, 1988), a market place (Sikes, 1992), an educational institution (Zeller, 1987; Hooper-Greenhill, 1990; Ballinger, 1993; Hein, G. 1998), or a contact zone (Clifford, 1997), the idea of a museum reflects the values of society.

What is actually reflected underneath the power of a museum's display is the philosophy of the museum staff. It is their belief, spoken or unspoken, that decides whether a museum should be a curiosity box, a history book, an adventure, or an unforgettable aesthetic experience. Becoming aware of the human element in museum settings has broadened my idea of the function of the art museum. I began to notice how the staff in art museums arranged objects. This led to my investigation of the education of museum professionals, wanting to know how they were trained and came to their beliefs.

The establishment of museum training programs is the result of the demands of museum realities. Each period of museum history marks its professionals' perceptions of museum practice. After the establishment of the American Association of Museums in 1906, training professionals for occupations in arts, library sciences, and museums became a focus in many universities (Spiess II, 1996a). Training museum professionals under appropriate disciplines in academic settings became a positive path for entering the museum field. In 1908, the first museum training programs were founded at the School of Industrial Art of the Pennsylvania Museum (now the Philadelphia Museum of Art). Museum studies programs have undertaken various reforms during the past century. Some museum professionals have insisted on providing a "discipline-based" entry training (Glaser \& Zenetou, 1996). Alternatively, some believed in "nuts and bolts" programs that focused on general museology (McKelvey, 1977). These points of view have formed the fundamental development of museum studies programs and still hold true in the United States today. 
The early museum establishment in the 1920 s and 30 s revealed the need for museum training programs. Leaders in museum fields laid out basic principles, qualifications, and training suggestions for museum studies programs. The belief that "A good museum person is born and not made"(Booth, cited in Glaser, 1990, p. 187) strongly ruled the museum field for more than three decades. It resulted in promoting museum work as scholarly and elite in nature and that only gifted persons were suitable for these high professions.

The growing number of museum studies programs in the 1960 s and 70 's reflected the public's concern toward museums. Since there was great demand in the field of museum work, more universities created museum studies programs. A need for setting a standard museum studies curriculum became a major concern among museum professionals. As a result, in 1973, American Associations of Museums established the Museum Curriculum Committee to offer suggestions for museum training institutions (Glaser, 1990).

In the 1980 s, the shift toward a more academic, discipline-based curriculum promoted professionalism in the museum settings. In the $1990 \mathrm{~s}$, the focus of education in the museums resulted in the great demand for museum educators. Today, facing a multilayered, post-modern, and inter-cultural society, ensuring quality training in a museum studies program has become a major concern (Suchy, 1998).

However, due to ongoing skepticism about whether training is necessary for a diverse museum environment, there has been continuous debate over the contents of museum studies programs in universities. Reynolds' question "Can you really be all things to all people - and if not, how do you teach students to deal with that in the communities in which they will work?"(Reynolds, cited in Spiess II, 1996b, p. 38) highlights the ambiguous relationship between the museum studies programs and the academic university setting. 
Reynolds' concern (cited in Spiess II, 1996b) lingered and eventually became the core of my study. In this research, I decided to explore the specific nature of museum studies programs in academic settings. My primary research question is: According to current museum professionals, do art-related museum studies programs in the United States adequately serve the staffing needs of art museums?

To answer this question, I first established the current state of museum studies programs in United States. Specifically, I wanted to know their mission statements, how they trained their students in preparation for museum careers, and what the performance records of the graduates were in the real art museum world. In addition, I wanted to know the fundamental differences between a knowledge-driven museum studies program in universities and an experienced-based museum work place. What did museum professionals perceive their needs to be in terms of staff? Is there an imbalance between theories and practices? If so, what can museum studies program do, in both the long and short term, to help museum apprentices prepare for the actual art museum business?

\section{Research Problem}

A literature review served as a guideline for me to identify current issues and concems in the field of museum training. Based on the scope of the literature review, my primary research question is: Do art-related museum studies programs in the United States adequately serve the staffing needs of art museums as perceived by current museum professionals? In addition, there are four fundamental questions raised in this study:

1. What is the current state of art-related museum study programs in the United States?

2. What do art museum professionals think an ideal art-related museum-training program should be?

3. Do the training programs satisfy the requirements of the current art museum environment? 
4. What does the analysis of art-related museum training programs and art museums' needs suggest for research and development of museum training programs in the future?

These questions formed the center of my studies in investigating the relationships between museum studies programs and the actual art museum field in the United States.

\section{Research Participants}

The subjects of this research are divided into two groups: (1) art-related museum studies programs' personnel; and (2) art museum professionals.

The first group, art-related museum studies program personnel, were drawn from the existing current art-related museum studies programs in the United States. The total number of museum studies programs in the United States is not certain, but based on Spiess II's (1996b) report, there are at least 130 institutions that offer museum training programs. However, according to AAM's (1999) recent survey, up to January 1999 , the total number of museum training programs in the United States is 575 . These 575 training sources range from degree or certificate-seeking programs in academic settings, non-degree or non-certificate-seeking workshops and summer camps, to mid-career training programs. Depending on the type of training, programs cultivate students for different museum fields. Some programs are content specific, such as training for a science museum environment. Other programs offer a mixture of general museology, preparing their students for all types of museums.

In order to have an in-depth point of view on the content of museum studies programs and to maintain my primary interests of training for art museums, this study focused on art-related degree/certificate-seeking museum studies programs in universities. To obtain a more up-to-date number of art-related certificate/degree-granting museum studies programs offered in the United States, I used Edson's (1995) International Directory of Museum Training: Programs and Practices of the Museum Profession, AAM's (1999) 1999-2000 Guide To Museum Studies and Training in the United States 
and Peterson's Guide to Graduate Programs in Business, Education, Health and Law (2001) to pinpoint additional results. Through this process, I also looked at the geographic distribution of art-related museum studies programs in the United States.

Another group, art museum professionals, was drawn from the art museums. Thirty art museums have participated in this research. To narrow down the study group from the vast pool of art museums, I applied two restricting rules. The first restriction is that the selected 30 art museums must be certified and approved by American Association of Museums (AAM). AAM is the only organization that promotes and assists the entire spectrum of museums in the United States. It "leads the effort to maintain and strengthen professional standards, through activities designed to improve the overall quality of museum programs and operations" (AAM, 2000, Goal, para. 1). Thus, a museum that is accredited by AAM has achieved a certain level excellence in its operation. Second, these 30 art museums are representative of a broad spectrum of art museums. This group of art museums is diverse with respect to their size (small, medium, and large), content (comprehensive and specific, focused in art), and location.

This study focuses on professionals who serve in the five major art museum positions. These positions are executive director, curator of exhibitions, curator of collections, curator of education, and development officer. According to Susan Olsen (personal communication, January 24, 2000), the former Chief of the Bureau of Historical Museums in Tallahassee, Florida, as well as a museum studies instructor at Florida State University, these five positions are the basic and most crucial in managing art museums. I took this approach in the belief that by specifying the area of study inside the structure of the museum, a clearer vision may emerge of the nature of art museum work experience. Although each art museum may name these positions differently, their job content is similar. By looking specifically at the content and experiences of these positions, I expect to find patterns among these positions to investigate the relationship between art-related 
certificate/degree-granting museum training programs in universities and art museum occupations.

\section{Research Method}

The design of this research applied both qualitative and descriptive quantitative research techniques. This research utilized multiple research methods: document-based content analysis, survey, and telephone or person-to-person interviews. Descriptive research was used to gather and document "form, structure, activity, change over time, relation to other phenomena" (Bog \& Gall, 1989, p. 5). This data was then used to analyze museum studies programs and determine their consequences - whether or not they succeeded in meeting the museum environment's demands. This strategy is similar to Wholey's definition of evaluation, which is to compare the "actual program performance with some standard of expected program performance, and the drawing of conclusions about a program's effectiveness and value" (Wholey, cited in Shadish, Cook \& Leviton, 1995, p. 227). However, I was more interested in the relationship and effectiveness between museum studies programs and art museums rather than drawing conclusions on the value of museum studies programs. The primary focus of this study was to compare museum studies programs' performance against a standard set by museum professionals.

Content analysis is employed throughout the study. Borg \& Gall (1989) recognize content analysis as "a research technique for the objective, systematic, and quantitative description of the manifest content of communication" (p. 519). Although content analysis can be quantitative in nature (Merriam, 1998), it also can be used inductively to merge themes and patterns of meaning. From the content of data, I developed categories for further interpretation. The process of charting possibilities from variables resulted in creating a typology (Merriam 1998). In addition, a constant comparative method was used to compare and contrast the three sets of results from document-based analysis, surveys, and interviews. 


\section{Research Procedure}

My procedure was as follows: First, I conducted document-based research on the existing art-related museum programs and art museum job requirements gathered from publications and resources. After obtaining a general understanding of the nature of museum studies and demands in art museum realities, I conducted a survey that addresses issues and patterns found from the results of document-based research as described below. Finally, interviews of museum studies program personals were conducted to gather more indepth information. By comparing and contrasting the findings, the relationship between artrelated museum studies programs and art museums emerges.

\section{Document-based Analysis}

In the first component, the document-based content analysis, the content and needs of both museum studies programs and art museum programs were studied using existing publications. The goal was to obtain a fundamental knowledge of the demands of working at art museums and of current museum studies programs.

To understand the content of museum studies programs in general, the primary data was published program descriptions from institutions that offer art-related museum studies programs in the United States. This information was obtained from the following sources: (1) AAM's (1999) 1999-2000 Guide To Museum Studies and Training in the United States; (2)Peterson's Guide to Graduate Programs in Business, Education, Health and Law (2001); and, (3) each selected institution's web sites as they were available. The significant information was their mission statements, the course design, and established affiliations with art museums.

In order to grasp an idea of the current demands in the art museum job market, the study focused on job descriptions in the art museum fields in the United States. The primary data was material gathered from Aviso, identified by Olsen (personal communication, February 28,2000 ) as the major source of job information in the museum field. It provides the latest AAM activities, services, and guidelines. It is also known as the 
museum professionals' job bank. Each issue provides an average of 125 job advertisements for museum-related positions (AAM, 2000, Aviso, para. 1). I focused on the job descriptions of the addressed five positions, namely executive director, curator of exhibitions, curator of collections, curator of education, and development officer in art museums. Basic requirements, job loads, and structure in relation to the art museum as a whole were the main concerns. The purpose was to have a basic understanding of what the art museum requested from people who are interested in museum careers.

Patterns created categories based on the job descriptions. Another set of categories was established based on the design of course work. Pairing the results from both sides (museum studies and art museums), I measured whether the goals from each are in accord with one another.

\section{Survey}

The second component was to conduct a survey, used as a descriptive method to further analyze the quality and accuracy of the study objectives (Fraenkel \& Wallen, 1996). Two sets of questionnaires were sent: one to existing art-related certificate/degree-granting museum study programs in the nation; the other, to the five selected positions in thirty selected art museums. I used Anderson, Eisner \& McRorie's (1998) study methods as guidelines to design survey procedures. Aspects addressed in Glaser \& Zenetou's (1996) questions considering museum studies programs were used when designing the survey questions.

In order to gather more precise and specific information, the structure of the questions in this survey consisted of various methods of inquiry: direct answer questions, open-ended questions, and closed ended questions (Dillman, 1978). Some questions involved additional follow-up questions to ascertain the respondents' perceived intent in their initial answers. These follow-up questions served to help understand the perceived meaning of different words or phrases in the questions. They also helped to affirm the answers and eliminate possible response-error problems due to misinterpretations of the 
words or phrases that are used in the prior (target) questions (Groves, Fultz, \& Martin, 1992).

There were two sections in the survey for the art museum professionals (five positions at selected thirty art museums). First, each participant was asked to provide a list of criteria for course work needed in museum training programs based on his/her experiences in the art museum field. The second part of this survey for art museum professionals consisted of questions on their identification and response toward current issues in the field of art museums. In addition, their perspectives on museum training programs were investigated. Questions such as, "How do you think museum studies programs should react when facing changes?' were utilized to gather their opinions on expectations for museum studies programs. Through gaining personal insight into the museum reality, I mapped out art museum professionals' ideas on the training content of museum studies programs. This section ended with a scenario question, "If you were to establish a certificate or degree-granting art-related museum studies programs for potential art museum professionals, how would you design your program?" This question provided art museum prof essionals' concepts of an ideal art-related museum studies program.

There were three components in the survey for art-related museum studies programs. The first section included important aspects in assessing the current state of museum studies programs. The questions addressed the faculties, the required courses, museum relations, student bodies, and the performance of the museum program graduates. The second part targeted the content of the course work, the design of curricula, and the strategies used to bridge theory and practice of museum work. The third part of this survey were questions on how each individual institution responds to current issues in art museums. Specifically, questions addressed each institution's self-evaluations on its performance in preparing art museum professionals for the selected five positions. 
Based on the finding from content analysis of the data, I paired up results from both sides (museum studies and art museums). I investigated if and how the training at art-related museum studies programs coincides with the art museum reality.

\section{Telephone or Face-to-face Interviews}

The last step was to interview five selected art-related museum studies institutions from the participants. The questions were structured with an open-ended nature. The interview questions included difficulties, achievements, and concerns for future art-related museum training. Information on conditions, strategies, and prospects for future art museum professionals were gathered as well. Based on each institution's unique experiences, I followed Seidman's (1998) Reflecting on the meaning questioning skills to gather participants' perceptions on the content of museum studies programs. This component served as a follow-up to document-based research and survey research to fill possible gaps in the research design.

\section{Conclusion}

Museums' missions are aimed at serving the public at large. The mission of a museum studies program is to cultivate museum professionals. The ultimate goal of museums and museum studies should be to provide sound management, a safe environment for collections, and a multitude of meaningful events to the general public (Woodhead \& Stansfield, 1989). The goal of museum studies programs is to help museums achieve their goals through educating properly trained museum professionals. In that context, I attempted to answer the question, "Do art-related museum studies programs in the United States adequately serve the staffing needs of art museums as perceived by current museum professionals?" 


\section{References}

American Association of Museums (AAM). (2000). Goal. [WWW document], Retrieved June 12, 2001, from URL http://www.aam-us.org/aamfaqs.htm American Association of Museums. (AAM) (2000). Aviso. [WWW document]. Retrieved June 12, 2001, from URL http://www.aam-us.org/pubp.htm American Association of Museums (AAM). (1999). Guide to museum studies and training in the United States: 1999-2000. Washington, DC: American Association of Museums.

Anderson, T, Eisner, E. \& McRorie, S. (1998). A survey of graduate study in art education. Studies in art education. 40(1), 8-25.

Ballinger, C. (1993). New survival strategies sought for museum education. Museums Journal.93 (7), 10.

Borg, W. R. \& Gall, M. D. (1989). Educational research: An introduction. NY: Longman. Clifford, J. (1997). Routes: Travel and translation in the late twentieth century, Cambridge, MA: Harvard University Press.

Dillman, D. (1978). Mail and telephone surveys: the total design method. NY: Routledge. Edson, G. (1995) International directory of museum training: Programs and practices of the museum profession. NY: Routledge.

Glaser, J. R. (1990) Museum studies in the United States: Toward professionalism. In J. W. Solinger (Eds.), Museums and universities: New paths for continuing education. (pp.185-198). NY: Macmillan Publishing Company.

Glaser, J. R.\& Zenetou, A. A. (1996) Museums: A place to work - planning museum careers. NY: Routledge in association with The Smithsonian Institution.

Groves, R. M., Fultz, N. H., \& Martin, E. (1992). Direct questioning about comprehension in a survey setting. In J. M. Tanur (Eds.), Questions about questions: Inquires into the cognitive bases of surveys. (pp. 98-130). Englewood Cliffs, NJ: Prentice Hall.

Hein, G. (1998) Leaming in the museum. NY: Routledge. 
Hooper-Greenhill, E. (1991) Museum and gallery education. Leicester, London: Leicester University Press.

McKelvey, F. (1977). Museum training programs: A discussion of current issue. NY: Cooperstown Graduate Association.

Margolis, J. (1988). The idea of an art museum. In L. Aagaard-Mogensen (Eds.), The idea of the museum: Philosophical. artistic and political questions. (pp. 171-194). Lewiston, NY: The Edwin Mellen Press.

Merriam, S. B. (1998). Qualitative research and case study applications in education. San Francisco, CA: Jessey-Bass Publication.

Peterson's guide to graduate programs in business, education. health. \& law. (2001). Princeton, NJ: Peterson's Guides.

Pope-Hennessy (1994) The museum: past, present, and future. In E.H. Gombrich (3 rd. Ed.) Ideals \& idols: essays on values in history and in art. ( pp. 189-204) London: Phaidon Press Limited.

Seidman, I. (1998). Interviewing as qualitative research: A guide for researchers in education and the social science. NY: Teachers College Press.

Shadish, W. R., Cook, T. D. \& Leviton, L. C. (1995). Foundations of program evaluation: Theories of practice. Thousand Oak, CA: SAGE Publications.

Sikes, M. (1992) Interpreting the Head Museum as a metaphoric structure: A critical and ethnographic study. (Doctoral dissertation, Florida State University). Dissertation Abstracts International, 53, 03A.

Spiess II, P. D. (1996a) Toward a new professionalism: American museums in the 1920 's and 1930's. Museum News, 75(2), 38-47.

Spiess II, P. D. (1996b) Museum studies: Are they doing their job? Museum News, 75 (6), $32-40$ 
Suchy, S. (1998). Grooming new millennium museum directors. In L. Anya-Petrivna (Eds.), Museum training and cultural diversity. (pp. 67-85). Australia: International Committee for the Training of Personnel.

Woodhead, P. \& Stansfield, G. (1989). Key guide to information sources in museum studies. NY: Mansell.

Zeller, T. (1987). Museums and the goals of art education. Art Education.40(1), $50-55$. 